On financial risk and the safe haven characteristics of Swiss franc exchange rates

Christian Grisse, Thomas Nitschka

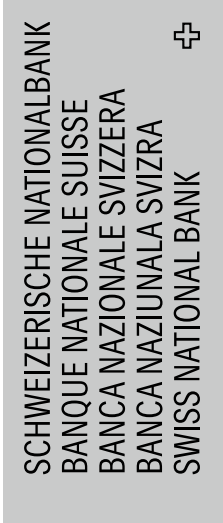


The views expressed in this paper are those of the author(s) and do not necessarily represent those of the Swiss National Bank. Working Papers describe research in progress. Their aim is to elicit comments and to further debate.

\section{Copyright ${ }^{\odot}$}

The Swiss National Bank (SNB) respects all third-party rights, in particular rights relating to works protected by copyright (information or data, wordings and depictions, to the extent that these are of an individual character). SNB publications containing a reference to a copyright ( $\odot$ Swiss National Bank/SNB, Zurich/year, or similar) may, under copyright law, only be used (reproduced, used via the internet, etc.) for non-commercial purposes and provided that the source is mentioned. Their use for commercial purposes is only permitted with the prior express consent of the SNB.

General information and data published without reference to a copyright may be used without mentioning the source.

To the extent that the information and data clearly derive from outside sources, the users of such information and data are obliged to respect any existing copyrights and to obtain the right of use from the relevant outside source themselves.

\section{Limitation of liability}

The SNB accepts no responsibility for any information it provides. Under no circumstances will it accept any liability for losses or damage which may result from the use of such information. This limitation of liability applies, in particular, to the topicality, accuracy, validity and availability of the information.

ISSN 1660-7716 (printed version)

ISSN 1660-7724 (online version)

๑ 2013 by Swiss National Bank, Börsenstrasse 15, P.0. Box, CH-8022 Zurich 


\title{
On financial risk and the safe haven characteristics of Swiss franc exchange rates
}

\author{
Christian Grisse $^{1}$
}

\author{
Thomas Nitschka
}

\author{
Swiss National Bank
}

April 2013

\begin{abstract}
We analyse bilateral Swiss franc exchange rate returns in an asset pricing framework to evaluate the Swiss franc's safe haven characteristics. A "safe haven" currency is a currency that offers hedging value against global risk, both on average and in particular in crisis episodes. To explore these issues we estimate the relationship between exchange rate returns and risk factors in augmented UIP regressions, using recently developed econometric methods to account for the possibility that the regression coefficients may be changing over time. Our results highlight that in response to increases in global risk the Swiss franc appreciates against the euro as well as against typical carry trade investment currencies such as the Australian dollar, but depreciates against the US dollar, the Yen and the British pound. Thus, the Swiss franc exhibits safe-haven characteristics against many, but not all other currencies. We find statistically significant time variation in the relationship between Swiss franc returns and risk factors, with this link becoming stronger in times of stress.
\end{abstract}

JEL: E32, F44, G15

Keywords: exchange rate, monetary policy, risk factors, safe haven, Swiss franc, uncovered interest rate parity

\footnotetext{
${ }^{1}$ E-mail: christian.grisse@snb.ch; thomas.nitschka@snb.ch We thank Katrin Assenmacher, two anonymous referees of the SNB working paper series, and participants in the SNB Brown Bag Seminar and the annual BuBa-OeNB-SNB workshop 2012 for helpful comments and suggestions. The views expressed in this paper do not necessarily reflect the view of the Swiss National Bank. Any errors and omissions are our own.
} 


\section{Introduction}

The recent crisis in the euro area has led to a massive appreciation of the Swiss franc, prompting the Swiss National Bank (SNB) to implement unconventional policy measures, including foreign exchange interventions and the introduction of an exchange rate floor against the euro. ${ }^{2}$ In this context, the usual explanation put forward for the strong Swiss franc appreciation is the status of the Swiss franc as the typical safe haven currency. ${ }^{3}$ Safe haven assets provide a hedge against risk on average. This characteristic is amplified in severe crises episodes during which safe haven assets particularly gain in value. High frequency analysis of Swiss franc exchange rate movements indeed leaves the impression of safe haven characteristics of the Swiss franc in several crises events (Ranaldo and Söderlind, 2010).

In this paper we argue that the Swiss franc exhibits safe haven asset characteristics against some currencies - such as the euro - but not against other major currencies, such as the US dollar and the Yen. We draw this conclusion from studying Swiss franc exchange rate changes in an asset pricing framework, using recently developed econometric methods to assess time variation in the relation between exchange rates and risk factors. A steadily growing literature argues that (ex post) deviations from the uncovered interest rate parity condition (UIP) can be rationalized by the covariation of exchange rate changes with risk factors (e.g. Bansal and Shaliastovich, 2010; Farhi and Gabaix, 2011; Lustig and Verdelhan, 2006, 2007; Lustig et al., 2011; Menkhoff et al., 2012; Ranaldo and Söderlind, 2010; Sarno et al., 2012; Verdelhan, 2010, 2012). Safe haven characteristics imply a close link to financial risk factors. It is hence natural to analyse Swiss franc exchange rate changes in this framework. We adopt the asset pricing framework of Verdelhan (2012), based on Backus et al. (2001) and Lustig et al. (2011), to analyse 11 bilateral Swiss franc exchange rate pairs

\footnotetext{
${ }^{2}$ In the 3 years leading up to the introduction of the exchange rate floor against the euro in September 2011 the Swiss franc appreciated almost $40 \%$ against the euro.

${ }^{3}$ See Habib and Stracca (2011) for an empirical assessment of the factors that determine a safe haven.
} 
during the time period from January 1990 to August 2011. This framework features one Swiss franc-specific and one global risk factor.

Our results highlight that the Swiss franc is a safe haven relative to many, but not all currencies: in response to increases in global risk the franc appreciates against the euro as well as against typical carry trade investment currencies such as the Australian dollar, but depreciates against the US dollar, the Yen and the British pound. Exploiting insights of Müller and Petalas (2010) on the estimation of time-varying regressions coefficients we find statistically significant time variation in the relationship between Swiss franc returns and risk factors, with this link becoming stronger in times of stress. For instance, on average a one percent increase in the VIX index - our baseline proxy for global risk - is associated with 0.04\% Swiss franc appreciation against the Australian dollar, and a $0.03 \%$ depreciation against the US dollar. Around the period of the Lehman bankruptcy, the change in the VIX index was associated with a more than $0.2 \%$ appreciation against the Australian dollar, and a more than $0.2 \%$ depreciation against the US dollar.

The remainder of the paper is organized as follows. Section 2 provides information about the conceptual background of this study. Section 3 describes the data sources. Section 4 presents the econometric framework and the main empirical results. Section 5 concludes.

\section{Conceptual background}

This section motivates the use of an asset pricing framework to explain exchange rate changes. It provides some basic, theoretical background and introduces recent advances in the formulation of empirical currency risk models that form the backbone of our empirical analysis.

\subsection{Financial risk factor augmented UIP regressions}

UIP states that under the assumption of rational expectations and risk-neutrality the expected exchange rate change reflects the previous period's interest rate differential between the home and foreign country, i.e. 


$$
E_{t}\left(\Delta s_{t+1}^{k}\right)=i_{t}^{k}-i_{t}
$$

where $i_{t}^{k}$ is the country $k$ interest rate, $i_{t}$ its home country counterpart, $\Delta s_{t+1}^{k}$ the change in the $\log$ spot exchange rate of country $k$ relative to the home currency and $E$ is the expectation operator. An increase in $s$ corresponds to an appreciation of the home and depreciation of the foreign currency. Hence, UIP implies that high-interest rate currencies should depreciate.

Interest rate differentials are approximately equal to forward discounts at least at the monthly frequency that we consider (e.g. Akram et al., 2008), such that

$$
i_{t}^{k}-i_{t} \approx f_{t}^{k}-s_{t}^{k}
$$

with $f_{t}^{k}$ the $\log$ forward exchange rate. The standard UIP regression for the bilateral exchange rate with country $k$ then has the following form:

$$
\Delta s_{t+1}^{k}=\alpha^{k}+\beta^{k}\left(f_{t}^{k}-s_{t}^{k}\right)+\varepsilon_{t+1}^{k}
$$

According to the UIP condition, the regression coefficient $\beta$ should be equal to unity and the constant term, $\alpha$, should be equal to zero.

However, starting with Tryon (1979), Hansen and Hodrick (1980) and Fama (1984), support for the UIP condition remains rather scarce. ${ }^{4}$ A potential explanation for the lack of empirical support is the presence of a risk premium required by market participants for a foreign currency investment (e.g. Bansal and Shaliastovich, 2010; Farhi and Gabaix, 2011; Lustig and Verdelhan, 2006, 2007; Lustig et al., 2011; Menkhoff et al., 2012; Ranaldo and Söderlind, 2010; Sarno et al., 2012; Verdelhan, 2010, 2012).

According to this asset pricing view on exchange rate determination, UIP regressions, such as (3), should be augmented by incorporating currency risk factors (Verdelhan, 2012). Such regressions could then take the following form

\footnotetext{
${ }^{4}$ Bansal and Dahlquist (2000) find that UIP holds for high inflation countries. Meredith and Chinn (2005) use long-term government bond yields as a proxy for risk-free rates to assess UIP at long horizons. They find that UIP holds quite well for horizons of 5 years or more. Lothian and $\mathrm{Wu}$ (2005) provide evidence that UIP holds over the long-term if we exclude the 1980s from the sample. Huisman et al. (1998) use a panel setup to show that UIP is violated but with significant, non-negative regression coefficients.
} 


$$
\Delta s_{t+1}^{k}=\alpha^{k}+\beta_{0}^{k}\left(f_{t}^{k}-s_{t}^{k}\right)+\beta_{1}^{k} \psi_{t+1}^{1}+\beta_{2}^{k} \psi_{t+1}^{2}+\ldots+\beta_{n}^{k} \psi_{t+1}^{n}+\varepsilon_{t+1}^{k}
$$

where $n$ denotes the numbers of risk factors in a currency risk premium model, $k$ represents currency $k$ and $\psi$ denotes a currency risk factor. This regression can be easily derived from a basic asset pricing model when interpreting the standard UIP relation as a (zero net) investment strategy and additionally assuming that the investor's discount factor is a linear function of the risk factors $\psi$. Note that such regressions assess exchange rate changes (or, in general, asset returns) in "risky" or "less risky" times as measured by the factors. Therefore, the exchange rate changes are regressed on contemporaneously measured factors (Verdelhan, 2012). We know at least since Meese and Rogoff (1983) that exchange rate changes are notoriously hard to predict. The asset pricing framework under study does not alter this conclusion. We remain agnostic whether this indeed constitutes a major puzzle for international finance (Bacchetta and van Wincoop, 2006) or whether it should not be too surprising (Engel and West, 2005).

\subsection{Risk factor model(s) of exchange rate changes}

This subsection highlights the line of thought that led to recent empirical asset pricing models on which we base our empirical analysis.

\subsubsection{Fama's conditions}

Typically, the $\beta$ coefficients in regressions of the type of equation (3) are found to be negative whereas UIP predicts estimates of $\beta=1$. If a risk premium is the explanation of the negative regression coefficient, then i) the covariance between the risk premium and the expected exchange rate change must be negative and ii) the variance of the risk premium must be higher than the variance of the expected exchange rate change (Fama, 1984). To see this, decompose the forward discount from equation (3) into a risk premium and expected exchange rate change component, i.e.

$$
\begin{aligned}
& f_{t}-s_{t}=\left(f_{t}-E_{t}\left(s_{t+1}\right)\right)+\left(E_{t}\left(s_{t+1}\right)-s_{t}\right) \\
& f_{t}-s_{t}=r p_{t}+\Delta s_{t}
\end{aligned}
$$


with $r p_{t}=f_{t}-E_{t}\left(s_{t+1}\right)$ interpreted as the risk premium and the expected depreciation denoted by $\Delta s_{t}=E_{t}\left(s_{t+1}\right)-s_{t}$. This implies for the regression coefficient $\beta$ in the typical UIP regression, equation (3), that

$$
\beta=\frac{\operatorname{cov}\left(\Delta s_{t}, r p_{t}+\Delta s_{t}\right)}{\operatorname{var}\left(r p_{t}+\Delta s_{t}\right)}=\frac{\operatorname{cov}\left(\Delta s_{t}, r p_{t}\right)+\operatorname{var}\left(\Delta s_{t}\right)}{\operatorname{var}\left(r p_{t}+\Delta s_{t}\right)}
$$

If the risk premium is constant, then $\beta=1$ as predicted by UIP. To generate a negative coefficient, the two Fama conditions mentioned above must be satisfied.

2.2.2 Fama's conditions and pricing models of exchange rate changes: some theoretical background

Satisfying the Fama conditions remains a high hurdle for all asset pricing models of exchange rates. Backus et al. (2001) illustrate this in the context of affine models of the term structure of interest rates. They consider two countries. In each country, a local currency denominated asset is priced via the basic asset pricing equation

$$
\begin{aligned}
& 1=E_{t}\left(m_{t+1} R_{t+1}\right) \\
& 1=E_{t}\left(m_{t+1}^{*} R_{t+1}^{*}\right)
\end{aligned}
$$

where the asterisk denotes a foreign variable, $R$ is the gross return on an asset denominated in local currency and $m$ denotes the stochastic discount factor.

The home discount factor should be useful to value the return on the foreign asset converted into home currency. Under the assumption of complete markets

$$
1=E_{t}\left(m_{t+1}\left(S_{t+1} / S_{t}\right) R_{t+1}^{*}\right)
$$

and

$$
E_{t}\left(m_{t+1}^{*} R_{t+1}^{*}\right)=E_{t}\left(m_{t+1}\left(S_{t+1} / S_{t}\right) R_{t+1}^{*}\right)
$$

such that

$$
m_{t+1}^{*} / m_{t+1}=S_{t+1} / S_{t}
$$

with $S=\exp (s)$, the spot exchange rate in levels. 
In addition, suppose that the price of a bond, $b$, obeys $b_{t}=E_{t} m_{t+1}$ and hence the (net) interest rate on this bond is given by $r_{t}=-\log b_{t}=-\log E_{t} m_{t+1}$. Then we can express the covered interest rate parity condition, equation (2), in terms of discount factors.

$$
f_{t}-s_{t}=\log E_{t} m_{t+1}^{*}-\log E_{t} m_{t+1}
$$

Backus et al. (2001) then show the implications of these derivations for the two components of the Fama (1984) decomposition of the forward discount. From equation (10) and (11) we know that the expected exchange rate change equals the difference in conditional means of the logarithms of the home and foreign discount factor, i.e. it is only affected by the first moments of the discount factors

$$
E_{t} s_{t+1}-s_{t}=E_{t} \log m_{t+1}^{*}-E_{t} \log m_{t+1}
$$

while the risk premium term reflects higher moments of the joint distribution of the discount factors because

$$
r p_{t}=\left(\log E_{t} m_{t+1}^{*}-E_{t} \log m_{t+1}^{*}\right)-\left(\log E_{t} m_{t+1}-E_{t} \log m_{t+1}\right)
$$

Under the assumption that the discount factors (means and variances) are governed by idiosyncratic and common state variables, Backus et al. (2001) highlight, in the context of term structure models such as Cox et al. (1985), that we can then distinguish two cases that deliver an asset pricing model potentially satisfying the Fama conditions.

In the first case, the discount factors are equally affected by the common state variable. Only idiosyncratic factors drive discount factors. In this case, we must allow for negative nominal interest rates to account for the negative regression coefficient in the UIP regressions. In the second case, the home and foreign discount factors differ in their dependence on a common state variable. If this difference is large enough, then such a model can generate the forward premium puzzle of a negative UIP regression coefficient. However, based on bilateral exchange rates, Backus et al. (2001) show that neither case gives a satisfying solution to the ex post deviation of the uncovered interest rate parity condition. 


\subsubsection{Fama's conditions and pricing models of exchange rate changes: recent empirical}

advances

Recently, Lustig et al. (2011) show that the two first principal components in portfolios of foreign currency risk premia, sorted according to currencies' forward discounts (interest rate differentials), correspond to a country-specific and a global risk factor of currency excess returns (ex post deviations from UIP) from the U.S. investor's perspective. Differences in the exposure to the global factor determine the average risk premium on the currency portfolios. The exposures of these currency portfolios to the country-specific factor are almost equal. Lustig et al. (2011) further show that their empirical model reflects an extension of the twocountry framework of Backus et al. (2001) to a multi-country, global context. In this model, the idiosyncratic factors play no role in the determination of currency risk premia. By forming portfolios of foreign currencies, Lustig et al. (2011) are able to ensure empirically that this is the case, i.e. average out idiosyncrasies of currency excess returns.

In addition, Lustig et al. (2011) in the context of currency excess returns and Verdelhan (2012) in the context of exchange rate changes show that these risk factors, extracted from portfolios of currency excess returns, are also informative about time series as well crosssectional variation in bilateral excess returns and bilateral exchange rate changes. Therefore we adopt this model as our baseline specification to study Swiss franc exchange rate returns.

\section{Data}

Our baseline sample period spans the time period from January 1990 to August 2011. The beginning of the sample period is limited by the availability of data for our proxies of (global) currency risk, while the end of the sample reflects the introduction of the minimum rate against the euro by the SNB in September 2011. We consider Swiss franc exchange rates relative to the Australian dollar, the Canadian dollar, the euro, the Japanese yen, the New Zealand dollar, the Norwegian krone, the Singaporean dollar, the South African rand, the 
Swedish krona, the British pound and the US dollar. Before the introduction of the euro in January 1999, we use the European Currency Unit (ECU) as proxy for the euro exchange rate. We obtain these exchange rates from cross-rates of US dollar exchange rates. The source of the respective end-of-month spot exchange rate data and the one-month forward rates are Barclays and WM/Reuters, available via Datastream. The sample of exchange rates is limited by the availability of exchange rate data over the entire sample period.

We focus on data at the monthly frequency because the augmented UIP regressions feature forward discounts as approximation of interest rate differentials. Hence, we assume that covered interest rate parity holds. This relation only holds at weekly or lower frequencies (e.g. Akram et al., 2008). Despite this limitation the use of forward discounts instead of interest rate differentials has some advantages. First, forward discounts are actually traded while money market rates, as e.g. Libor rates, do not necessarily reflect actual transactions. Second, UIP requires that interest rates reflect the same "riskiness". Again, the use of money market rates or even government bond yields could lead to violations of this requirement.

Moreover, we employ changes and levels in the CBOE option-implied volatility index of the S\&P 500, VIX, based on end of month close prices as a proxy of global currency risk. The VIX series is obtained directly from the CBOE website. As an additional check for euro area specific risks we use the yield spread (in percentage points p.a.) between Italian and German government bonds with constant 10-year maturity from Datastream. The sample period for this data is April 1991 to August 2011. Furthermore, we employ the TED spread, i.e. the spread between a 3-month US Treasury bill and the 3-month Eurodollar deposit rate in percentage points p.a., as measure of funding liquidity risk and hence as additional control variable in our robustness checks (Brunnermeier et al., 2009). 


\section{$4 \quad$ Econometric framework and empirical results}

Taking currency risk factors into account enhances our understanding of exchange rate dynamics. Section 4.1 provides evidence supporting that point. Section 4.2 assesses the time variation in the exchange rate - risk factor relation.

\section{1 (Augmented) UIP regressions}

This section highlights the usefulness of the asset pricing view of exchange rates for studying Swiss franc returns. We start by showing the results of standard UIP regressions for the Swiss franc which provide the motivation to use empirical models augmented by currency risk factors. The second subsection presents the results for these models. The third subsection summarizes a series of robustness checks.

\subsubsection{UIP regressions}

This section documents the well-known lack of empirical support for the uncovered interest rate parity condition in the context of the Swiss franc exchange rates under study. Table 1 provides estimates of $\alpha^{k}$ and $\beta_{0}^{k}$ from monthly UIP regressions

$$
\Delta s_{t+1}^{k}=\alpha^{k}+\beta_{0}^{k}\left(f_{t}^{k}-s_{t}^{k}\right)+\varepsilon_{t+1}^{k}
$$

where $k$ denotes one of bilateral Swiss franc exchange rates and $s$ and $f$ represent log spot exchange rate changes and 1-month log forward rates respectively. Newey-West (Newey and West, 1987) corrected standard errors appear below the point estimates in parentheses. The $R^{2}$ statistic is adjusted for the number of regressors. The Durbin-Watson statistic (DW) indicates if there is autocorrelation in the regression residuals. The sample period runs from January 1990 to August 2011.

The results summarized in Table 1 show that UIP is typically violated ex post, i.e. the point estimates of $\beta_{0}^{k}$ are significantly different from unity. Exceptions are the Swedish krona and the Singaporean dollar. In most cases, however, the point estimates are negative albeit not always significantly different from zero, i.e. lagged forward discounts explain little of the 
time variation in Swiss franc exchange rate changes. The respective measures of fit range from $0 \%$ to $4 \%$. Since the negative point estimate could be the reflection of a risk premium on foreign currency investment, we augment the standard UIP regression with currency risk factors and evaluate the potential covariation of the Swiss franc exchange rate changes with these risk factors in the subsequent section.

\section{[about here Table 1]}

\subsubsection{Augmented UIP regressions}

In this subsection, we assess if the consideration of potential currency risk factors helps to better understand exchange rate dynamics. In our baseline specification, we closely follow Verdelhan (2012) and Lustig et al. (2011) and adopt their asset pricing framework to the Swiss franc exchange rate context. We consider different specifications as robustness checks and summarize these results in a separate, subsequent subsection.

Our baseline currency pricing model consists of two risk factors (Lustig et al., 2011). The first factor is the average Swiss franc exchange rate change. It is a currency-specific factor as shown by Lustig et al. (2011). We exclude the exchange rate whose dynamics we evaluate from the calculation of the currency-specific factor as recommended by Verdelhan (2012). For example, when we examine the Swiss franc - euro exchange rate changes in the augmented UIP regressions, we use the arithmetic average of the other 10 Swiss franc exchange rate changes as first risk factor. Verdelhan (2012) shows that this average of exchange rate changes indeed corresponds to a risk factor on currency markets. He shows that, from the perspective of a US investor, returns on currencies sorted in portfolios according to their exposure to this factor reveal strong cross-sectional differences.

As a second risk factor, we employ returns in the VIX index. This second risk factor is a measure of global risk on currency markets. We exploit that the empirical proxy of the global risk factor by Lustig et al. (2011), differences in the returns on high and low forward discount sorted currency baskets, is positively correlated with innovations in global equity market 
volatility. VIX returns are our proxy of innovations in global equity market volatility and hence our approximation of the global factor in the original Lustig et al. (2011) model. This VIX index is also highly positively correlated with volatility indices of other equity markets. The use of this equity market volatility series as proxy of global risk helps to avoid potential double counting in the augmented UIP regressions. The global factor in Lustig et al. (2011) is constructed from currency portfolios sorted on forward discounts/ interest rate differentials. Hence, including this factor directly in a regression together with the bilateral forward discount rate of the exchange rate under study could create econometric issues since that particular currency pair or a cross rate is included in the Lustig et al. (2011) global risk factor. We therefore prefer to use a global risk factor proxy that is neither constructed from interest rate differentials / forward discounts nor from exchange rate data.

The augmented UIP regressions then take the following form

$$
\Delta s_{t+1}^{k}=\alpha^{k}+\beta_{0}^{k}\left(f_{t}^{k}-s_{t}^{k}\right)+\beta_{1}^{k} A F X_{t+1}+\beta_{2}^{k} \Delta V I X_{t+1}+\varepsilon_{t+1}^{k}
$$

with $A F X$ abbreviating average Swiss franc exchange rate changes excluding currency $k$ and $\triangle V I X$ representing log changes in the CBOE option-implied volatility index, VIX. The regression results are summarized in Table 2. Again Newey-West (Newey and West, 1987) corrected standard errors appear below the point estimates in parentheses. The sample period runs from January 1990 to August 2011.

Several observations are noteworthy. First, the coefficients on the forward discount remain in most cases not statistically significant. Second, we observe pronounced variation in the sensitivity to the Swiss franc-specific currency risk factor, AFX. The estimates range from 1.4 for the Canadian dollar to 0.4 for the euro. One potential reason why Swiss franc-euro returns are less strongly related to Swiss franc movements against other currencies may be the fact that the Swiss economy is closely linked to the euro area, dominating the effects from the "rest-of-the-world". Recall that the respective AFX series do not include the bilateral exchange rates that we evaluate in the respective regression. Third, the covariation of Swiss 
franc exchange rates with VIX returns shows that the Swiss franc exhibits safe haven characteristics against many, but not against all other currencies. The coefficient $\beta_{2}^{k}$ reflects both the Swiss franc's status as a safe haven and the franc's role as a typical funding currency in currency carry trades. Negative coefficient estimates indicate that the Swiss franc appreciates against the respective currency when the VIX, i.e. global risk, increases. This is the case for the Swiss franc exchange rates against the typical investment currencies in carry trades such as the Australian dollar, the New Zealand dollar or the South African rand. By contrast, significant positive coefficients signal that the Swiss franc depreciates against the respective currency when global risk increases. This is the case for the Swiss franc exchange rates against the Japanese Yen, the British pound and the US dollar. On average, these currencies provide a better hedge against global risk than the Swiss franc. Finally, corroborating Verdelhan (2012), the augmented UIP regressions provide a better fit of the data than the standard UIP regressions. The $R^{2}$ statistics range from $20 \%$ to $70 \%$ compared with $0 \%$ to $4 \%$ in the standard UIP regressions.

\section{[about here Table 2]}

A potential, general critique of our approach is that there could be structural breaks during the sample. In particular, one might argue that the foreign exchange interventions undertaken by the SNB since 2009 have changed the underlying "true" asset pricing relationship that determines Swiss franc exchange rate changes, and that ideally one should somehow control for SNB policy measures, for example by including a measure of the size of interventions as an additional control variable in the regression. However, the relevance of uncovered interest parity and the underlying risk-return relationship (15) for investors is unaltered by the presence of central bank interventions. Central bank interventions could, however, have changed the magnitude of the regression coefficients and thus have changed the exchange rate change - risk factor relation over time. We analyse potential time variation in section 4.2. 


\subsubsection{Robustness Checks}

To check the robustness of our baseline specification we conduct a number of additional analyses summarized below. To conserve space, we do not report the detailed results but all of them are available upon request.

First, we add the spread (in levels or changes) between Italian and German 10-year government bond yields as a control variable for specific euro area risks to the baseline regression setup. Since the Swiss economy is closely related to the euro area, one might argue that it is not necessarily Swiss-specific or global risk but the materialization of euro area risks that influences Swiss franc exchange rate changes. The Italian-German bond yield spread appears to be a good proxy for these risks. The spread is particularly high in the early to mid1990s when the European exchange rate mechanism experienced a crisis episode and in the recent past reflecting the euro area sovereign debt issues. It turns out that the regression coefficients of the bond spread in almost all regressions (even in the euro regression) are not statistically significant. Including the bond spread does not change any of the estimates of the baseline specification and does not improve the regression fit.

Second, we assess if our baseline results hold once we include a measure of funding liquidity risk. We use the TED spread (in levels or changes), proposed by Brunnermeier et al. (2009), for that purpose. The TED spread is commonly thought of as a measure of investors' funding liquidity risk. If the spread is low there is little funding liquidity risk, while a large and negative spread indicates funding liquidity risk. Brunnermeier et al. (2009) show that the TED spread is a good explanatory variable for carry trade returns. Although we find significant comovement between Swiss franc exchange rate returns and the TED spread, none of the baseline specification estimates is altered.

As a third robustness check, we use the level of VIX instead of changes in VIX in the augmented UIP regressions. For instance, Ranaldo and Söderlind (2010) use the level of VIX in their high frequency assessment of safe haven currencies as one potential risk factor. 
Interestingly, we find only little covariation between monthly exchange rate returns and the level of VIX. At this relatively low frequency returns in the VIX index seem to be a better proxy of global risk, which is in line with Lustig et al. (2011) and the finding that their global risk factor is highly correlated with innovations in global equity market volatility rather than with volatility levels.

Finally, we follow Engel et al. (2012) and extract principal components from the Swiss franc exchange rates under study. We then use these principal components as proxy of risk factors. Since a direct link between exchange rate changes and macroeconomic aggregates is difficult to detect in the data, Engel et al. (2012) argue that the principal components could be interpreted as reflection of fundamental determinants of exchange rate changes. In our context, the first three principal components explain about $80 \%$ of the common variation in the Swiss franc exchange rate changes. On the first principal component all Swiss franc exchange rates load positively. It is closely correlated with the average exchange rate return. Interestingly, the third principal component could reflect carry trade risk as we observe clear differences in the loading on that principal component between typical funding currencies such as the Yen and US dollar and investment currencies such as the Australian dollar or the South African rand. Regressions of Swiss franc returns on the three principal components provide a slightly better fit, in terms of $R^{2}$ statistics, than our baseline specification. However, this better fit comes at the cost of an unclear economic interpretation of the principal components, which is particularly the case for the second principal component.

\subsection{Time variation in the exchange rate - risk factor relation}

The previous section analysed the Swiss franc's safe-haven characteristics by estimating the relationship between bilateral Swiss franc exchange rate returns and risk factors. However, it is intuitive that this relationship is likely to be changing over time. First, safe haven assets typically provide hedging value against risk events on average, but in particular also in times of financial stress (e.g. Ranaldo and Söderlind, 2010). Thus the comovement between returns 
on safe-haven assets and risk factors can be expected to increase in financial crisis episodes (when risk factors are elevated). Second, as discussed above, the SNB's FX interventions in 2008-2011 could potentially have affected the link between Swiss franc movements and risk factors. To explore these issues we employ recently developed econometric methods to estimate the time variation in the coefficients of the baseline augmented-UIP regression (15), using log returns in the VIX index as the baseline measure of global risk. Our analysis is complementary to that of Ranaldo and Söderlind (2010): while they allow for nonlinearities in the relationship between safe haven assets and risk factors we instead estimate directly how this relationship has changed over time. ${ }^{5}$

We begin by reporting statistical tests for joint stability of the parameters in regression (15). To do this we employ the quasi-local-level test proposed by Elliott \& Müller (2006). ${ }^{6}$ The advantage of this test is that it is equivalent in large samples to the optimal tests for a wide range of possible statistical processes for time variation. Therefore we do not have to make specific assumptions about the particular process for time variation considered in the alternative hypothesis. The null of joint stability of the coefficients in (15) is rejected if the test statistic is smaller (more negative) than the critical values. We find that except for the CAD, SAR and GBP regressions the null of parameter stability can be rejected for all other currency pairs at the $5 \%$ level.

We then proceed to estimate the parameter paths for the coefficients, focusing on those bilateral rates where the null of parameter stability was rejected. To do this we use the method proposed by Müller and Petalas (2010) which provides an approximation to the sample

\footnotetext{
${ }^{5}$ Hoffmann and Suter (2010) study five Swiss franc exchange rates in a conditional asset pricing framework over the period from 1990 to 2009. They regress these exchange rate returns on a global risk factor and an interaction term between the global risk factor and the respective currency pair's interest rate differential to study the Swiss franc's role as a safe haven. The interaction term captures the time variation in potential safe haven characteristics. Hoffmann and Suter (2010) argue that interest rate differentials are good signals of the safe haven status of a currency. While this is a natural starting point, Habib and Stracca (2011) point out that there are a couple of other macroeconomic variables that potentially signal the safe haven status of currencies. In addition, the importance of these macroeconomic variables as signals of safe haven status could also vary over time. The method that we use instead allows to estimate directly how this relationship varies over time without relying on instrumental variables.

${ }^{6}$ This test has so far only been used in few applied papers, including Goldberg and Klein (2011).
} 
information about the parameter path that is accurate and efficient in large samples, independent from the precise nature of the underlying process of time variation. Since we know from the currency risk factor literature that differences in the sensitivities to the proxy of global risk determine differences in exchange rate changes, we focus on the presentation of the time-varying path of the global risk measure coefficients. Figure 1 reports the results for selected currency pairs.

\section{[about here Figure 1]}

The largest movements in coefficients occur during financial crisis episodes, with coefficients peaking around the period of the Lehman bankruptcy and (for USD and JPY) during the period of the Asian-Russian financial crises in 1997-1998. Responses to movements in the risk factor are much larger in times of financial stress. For example, Table 2 reported that a $1 \%$ monthly increase in the VIX index is associated with a $0.04 \%$ appreciation of the Swiss franc versus the Australian dollar on average over the sample. In contrast, allowing for time variation shows that at the height of the global financial crisis in late 2008 a $1 \%$ increase in the VIX led to a $0.2 \% \mathrm{CHF}$ appreciation against AUD, more than 5 times larger than the average effect. Confirming the findings from Table 2 for average comovements between Swiss franc returns and risk factors, during episodes of financial stress the negative relationship between Swiss franc returns against AUD, NZD and EUR and risk factors - with the Swiss franc appreciating in response to increases in the VIX index - becomes stronger: the Swiss franc's safe-haven role is particularly pronounced during crisis episodes. Conversely, the Swiss franc depreciates more sharply against USD and JPY in response to increases in the risk factor when risk is elevated. Thus the finding from the baseline regressions that the Swiss franc can be a considered a safe haven, in terms of its average hedging value, relative to EUR, AUD and NZD, but not relative to USD and JPY carries over to the definition of "safe haven" as an asset that gains in value in high-risk episodes. 


\section{Conclusions}

This paper estimates an asset pricing model relating bilateral Swiss franc exchange rate returns to alternative risk factors. We also explore how the influence of the risk factors changes over time, in particular between risk episodes and tranquil periods. We find that the Swiss franc does not behave like a safe haven asset against all currencies. The US dollar, the yen and the pound provide a better hedge against global risk than the Swiss franc. This finding could reflect the limited size of Swiss franc-denominated asset markets and hence limited market liquidity. Nevertheless, we find that the Swiss franc appreciates against many currencies, including the euro, when measures of global risk increase. This is the case both on average and in particular in times of financial stress. The safe haven characteristics of the Swiss franc-euro exchange rate are most clearly present since the onset of financial market stress in the euro area. This finding is in line with the view that peso problems or crash risk explain exchange rate dynamics as proposed by Burnside et al. (2011) and Farhi et al. (2009). The expectation of a small probability, but potentially catastrophic, event in the euro area could be an explanation of the Swiss franc's safe haven property relative to the euro in the recent past. 


\section{References}

Akram, Q. Farook, Dagfinn Rime and Lucio Sarno (2008), "Arbitrage in the Foreign Exchange Market: Turning on the Microscope", Journal of International Economics 76, 237253.

Bacchetta, Philippe and Eric van Wincoop (2006), "Can Information Heterogeneity Explain the Exchange Rate Determination Puzzle?", American Economic Review 96, 552-576.

Backus, David K., Silverio Foresi and Chris I. Telmer (2001), "Affine Term Structure Models and the Forward Premium Anomaly", Journal of Finance 56, 279-304.

Bansal, Ravi and Magnus Dahlquist (2000), "The Forward Premium Puzzle: Different Tales from Developed and Emerging Markets", Journal of International Economics 51, 115-144.

Bansal, Ravi and Ivan Shaliastovich (2010), “A Long-Run Risks Explanation of Predictability Puzzles in Bond and Currency Markets", unpublished working paper, Duke University.

Brunnermeier, Markus K., Stefan Nagel and Lasse H. Pedersen (2009), "Carry Trades and Currency Crashes", NBER Macroeconomic Annual 2008, Vol. 23, 313-347.

Burnside, Craig, Martin Eichenbaum, Isaac Kleshchelski and Sergio Rebelo (2011), "Do Peso Problems Explain the Returns to the Carry Trade", Review of Financial Studies 24, 853-891.

Christiansen, Charlotte, Angelo Ranaldo and Paul Söderlind (2011), "The Time-Varying Systematic Risk of Carry Trade Strategies", Journal of Financial and Quantitative Analysis 46, 1107-1125.

Cox, John, Jonathan Ingersoll and Stephen Ross (1985), "A Theory of the Term Structure of Interest Rates", Econometrica 53, 385-407.

Engel, Charles, Nelson C. Mark and Kenneth D. West (2012), „Factor Model Forecasts of Exchange Rates", unpublished working paper University of Wisconsin and University of Notre Dame.

Engel, Charles and Kenneth D. West (2005),. "Exchange Rates and Fundamentals“, Journal of Political Economy 113, 485-517.

Elliott, Graham and Ulrich K. Müller (2006), "Efficient Tests for General Persistent Time Variation in Regression Coefficients", Review of Economic Studies 73, 907-940.

Fama, Eugene F. (1984), "Forward and Spot Exchange Rates", Journal of Monetary Economics 14, 319-338.

Farhi, Emanuel, Samuel Fraiberger, Xavier Garbaix, Romain Ranciere and Adrien Verdelhan (2009), "Crash Risk in Currency Markets", unpublished working paper.

Farhi, Emanuel and Xavier Garbaix (2011), "Rare Disasters and Exchange Rates", unpublished working paper NBER, NYU Stern and Harvard University. 
Goldberg, Linda S. and Michael W. Klein (2011), "Evolving perceptions of central bank credibility: the ECB experience“, NBER Macroeconomics Annual 2010, 153-182.

Habib, Maurizio Michael and Livio Stracca (2011), "Getting Beyond Carry Trade. What Makes a Safe Haven Currency?”, ECB Working Paper No 1288.

Hansen, Lars P. and Robert J. Hodrick (1980), "Forward Exchange Rates as Optimal Predictors of Future Spot Rates: An Econometric Analysis”, Journal of Political Economy 88, 829-853.

Hoffmann, Mathias and Rahel Suter (2010), "The Swiss Franc Exchange Rate and Deviations From Uncovered Interest Rate Parity: Global vs Domestic Factors", Swiss Journal of Economics and Statistics 146, 349-371.

Husiman, Ronald, Kees Koedijk, Clemens Kool and Francois Nissen (1998), "Extreme Support for Uncovered Interest Rate Parity", Journal of International Money and Finance 17, 211-228.

Lothian, James R. and Liuren Wu (2005), "Uncovered Interest-Rate Parity over the Past Two Centuries", unpublished working paper Fordham University.

Lustig, Hanno, Nikolai Roussanov and Adrien Verdelhan (2011), "Common Risk Factors in Currency Markets", Review of Financial Studies 24, 3731-3777.

Lustig, Hanno and Adrien Verdelhan (2006), "Investing In Foreign Currency Is Like Betting On Your Intertemporal Marginal Rate Of Substitution", Journal of the European Economic Association 4, 644-655.

Lustig, Hanno and Adrien Verdelhan (2007), "The Cross-section of Foreign Currency Risk Premia and U.S. Consumption Growth Risk”, American Economic Review 97, 89-117.

McCauley, Robert N. and Patrick McGuire (2009), "Dollar appreciation in 2008: Safe Haven, Carry Trades, Dollar Shortage and Overhedging", BIS Quarterly Review, December 2009, 8592.

Meese, Richard A. and Kenneth Rogoff (1983), "Empirical Exchange Rate Models of the Seventies: Do They Fit Out of Sample?", Journal of International Economics 14, 3-24.

Menkhoff, Lukas, Lucio Sarno, Maik Schmeling and Andreas Schrimpf (2012), "Carry Trades and Global Foreign Exchange Volatility”, Journal of Finance 67, 681-718.

Meredith, Guy and Menzie D. Chinn (2005), "Testing Uncovered Interest Rate Parity at Short and Long Horizons during the Post-Bretton Woods Era”, NBER working paper 11077.

Müller, Ulrich K. and Philippe-Emmanuel Petalas (2010), "Efficient Estimation of the Parameter Path in Unstable Time Series Models", Review of Economic Studies 77, 1508-1539.

Newey Whitney K. and Kenneth D. West (1987), "A Simple, Positive Semidefinite, Heteroskedasticity and Autocorrelation Consistent Covariance Matrix", Econometrica 55, 703-708. 
Ranaldo, Angelo and Paul Söderlind (2010), "Safe Haven Currencies", Review of Finance 14, 385-407.

Sarno, Lucio, Paul Schneider and Christian Wagner (2012), "Properties of Foreign Exchange Rate Premiums", Journal of Financial Economics 105, 279-310.

Tryon, Ralph (1979), “Testing For Rational Expectations In Foreign Exchange Markets”, International Finance Discussion Papers No. 139, Board of Governors of the Federal Reserve System.

Verdelhan, Adrien (2010), "A Habit-Based Explanation of the Exchange Rate Risk Premium”, Journal of Finance 55, 123-147.

Verdelhan, Adrien (2012), "The Share of Systematic Risk in Bilateral Exchange Rates", unpublished working paper MIT Sloan and NBER. 
Table 1: UIP regressions

\begin{tabular}{|c|c|c|c|c|}
\hline & $\alpha^{k}$ & $\beta_{0}^{k}$ & $R^{2}$ & $\overline{\mathrm{DWW}}$ \\
\hline AUS & $-\underset{(0.01)}{0.00}$ & $\underset{(1.29)}{0.13}$ & 0.00 & 1.94 \\
\hline CND & $-\underset{(0.00)}{0.00}$ & $-{ }_{(-1.37)}^{0.75}$ & 0.00 & 2.11 \\
\hline EURO & $-\underset{(0.00)}{0.00}$ & $-\underbrace{1.54}_{(1.15)}$ & 0.01 & 2.29 \\
\hline JPN & $\begin{array}{l}0.00 \\
(0.00)\end{array}$ & $-{ }_{(0.72)}^{1.71} *$ & 0.01 & 1.98 \\
\hline NZL & $-\underset{(0.00)}{0.00}$ & $-\underset{(0.89)}{0.12}$ & 0.00 & 1.90 \\
\hline NOR & $-\underset{(0.00)}{0.00}$ & $-\underset{(1.05)}{0.96}$ & 0.01 & 2.21 \\
\hline SIN & $-\underset{(0.00)}{0.00}$ & $\begin{array}{l}0.56 \\
(0.86)\end{array}$ & 0.00 & 1.95 \\
\hline SA & $-\underset{(0.00)}{0.01} *$ & $-\underset{(0.10)}{0.42} *$ & 0.04 & 1.99 \\
\hline SWE & $-\underset{(0.00)}{0.00}$ & $\begin{array}{l}1.07 \\
(0.66)\end{array}$ & 0.01 & 2.10 \\
\hline UK & $-\underset{(0.00)}{0.01} *$ & $-\underset{(0.83)}{1.30}$ & 0.00 & 1.99 \\
\hline US & $-\underset{(0.00)}{0.00}$ & $-\underset{(1.09)}{1.54}$ & 0.01 & 1.91 \\
\hline
\end{tabular}

Notes: This table presents estimates from regressions of Swiss franc exchange rate returns (Swiss franc relative to Australian dollar, Canadian Dollar, euro, Japanese yen, New Zealand dollar, Norwegian krone, Singaporean dollar, South African rand, Swedish krona, British pound and US dollar) on a constant and the respective forward discount, i.e.

$$
\Delta s_{t+1}^{k}=\alpha^{k}+\beta_{0}^{k}\left(f_{t}^{k}-s_{t}^{k}\right)+\varepsilon_{t+1}^{k}
$$

where $k$ denotes the currency pairs and $s$ and $f$ represent log spot exchange rates and 1-month log forward rates, respectively. Newey-West (Newey and West, 1987) corrected standard errors appear below the point estimates in parentheses. The $R^{2}$ statistic is adjusted for the number of regressors. An asterisk indicates that estimates are significantly different from zero at $95 \%$ confidence level. We report the Durbin-Watson statistic for the autocorrelation of the regression residuals under the column "DW". The sample period runs from January 1990 to August 2011. 
Table 2: Augmented UIP regressions

\begin{tabular}{|c|c|c|c|c|c|c|}
\hline & $\alpha^{k}$ & $\overline{\beta_{0}^{k}}$ & $\overline{\beta_{1}^{k}}$ & $\beta_{2}^{k}$ & $R^{2}$ & DW \\
\hline & (constant) & $\left(f_{t}^{k}-s_{t}^{k}\right)$ & $\left(A F X_{t+1}\right)$ & $\left(\Delta V I X_{t+1}\right)$ & & \\
\hline AUS & $\begin{array}{l}0.00 \\
(0.00)\end{array}$ & $\underset{(0.63)}{0.26}$ & $\underset{(0.09)}{1.29}$ & $-\underset{(0.01)}{0.04} *$ & 0.65 & 2.01 \\
\hline CND & $\begin{array}{l}0.00 \\
(0.00)\end{array}$ & $-\underset{(0.55)}{0.55}$ & $\underset{(0.05)}{1.37} *$ & $-\frac{0.00}{(0.00)}$ & 0.71 & 2.24 \\
\hline EURO & $-\underset{(0.00)}{0.00}$ & $-\underset{(0.93)}{0.95}$ & $\underset{(0.05)}{0.35 *}$ & $\frac{-0.01}{(0.00)}$ & 0.33 & 2.19 \\
\hline JPN & $\begin{array}{l}0.00 \\
(0.00)\end{array}$ & $-\underset{(0.70)}{1.44} *$ & $\begin{array}{l}0.64 \\
(0.10)\end{array}$ & $\underset{(0.01)}{0.03}$ * & 0.18 & 1.91 \\
\hline NZL & $\begin{array}{l}0.00 \\
(0.00)\end{array}$ & $\begin{array}{l}0.09 \\
(0.72)\end{array}$ & $\frac{1.04}{(0.10)}$ & $-\underset{(0.01)}{0.02} *$ & 0.50 & 1.98 \\
\hline NOR & $-\underset{(0.00)}{0.00}$ & $-\underset{(0.82)}{0.31}$ & $\underset{(0.10)}{0.59} *$ & $-\underset{(0.01)}{0.01}$ & 0.36 & 2.14 \\
\hline SIN & $\begin{array}{l}0.00 \\
(0.00)\end{array}$ & $\underset{(0.31)}{0.71}$ & $\frac{1.09}{(0.06)}$ & $\underset{(0.01)}{0.02} *$ & 0.73 & 1.84 \\
\hline SA & $-\underset{(0.00)}{0.01} *$ & $-\underset{(0.10)}{0.39} *$ & $\underset{(0.10)}{1.08} *$ & $-\underset{(0.01)}{0.05}$ * & 0.43 & 2.06 \\
\hline SWE & $\begin{array}{c}-0.00 \\
(0.00)\end{array}$ & $\begin{array}{l}0.22 \\
(0.70)\end{array}$ & $\underset{(0.09)}{0.54} *$ & $-\underset{(0.01)}{0.02}$ * & 0.30 & 1.90 \\
\hline UK & $-\underset{(0.00)}{0.00}$ & $-\underset{(0.53)}{0.78}$ & $\underset{(0.11)}{0.81} *$ & $\underset{(0.01)}{0.02} *$ & 0.42 & 1.97 \\
\hline US & $-\underset{(0.00)}{0.00}$ & $-\underset{(0.56)}{0.23}$ & $\underset{(0.06)}{1.20} *$ & $\underset{(0.01)}{0.03} *$ & 0.60 & 1.70 \\
\hline
\end{tabular}

Notes: This table presents estimates from regressions of Swiss franc exchange rate changes (Swiss franc relative to Australian dollar, Canadian Dollar, euro, Japanese yen, New Zealand dollar, Norwegian krone, Singaporean dollar, South African rand, Swedish krona, British pound and US dollar) on a constant, the respective forward discount and two contemporaneously measured risk factors, i.e.

$$
\Delta s_{t+1}^{k}=\alpha^{k}+\beta_{0}^{k}\left(f_{t}^{k}-s_{t}^{k}\right)+\beta_{1}^{k} A F X_{t+1}+\beta_{2}^{k} \Delta V I X_{t+1}+\varepsilon_{t+1}^{k}
$$

with AFX abbreviating average Swiss franc exchange rate returns excluding currency $\mathrm{k}$ and $\Delta V I X$ representing log changes in the CBOE option-implied volatility index, VIX. $k$ denotes the currency pairs and $s$ and $f$ represent log spot exchange rate and 1-month log forward rates respectively. Newey-West (Newey and West, 1987) corrected standard errors appear below the point estimates in parentheses. The $R^{2}$ statistic is adjusted for the number of regressors. An asterisk indicates that estimates are significantly different from zero at 95\% confidence level. We report the Durbin-Watson statistic for the autocorrelation of the regression residuals under the column "DW". The sample period runs from January 1990 to August 2011. 


\section{Figures}
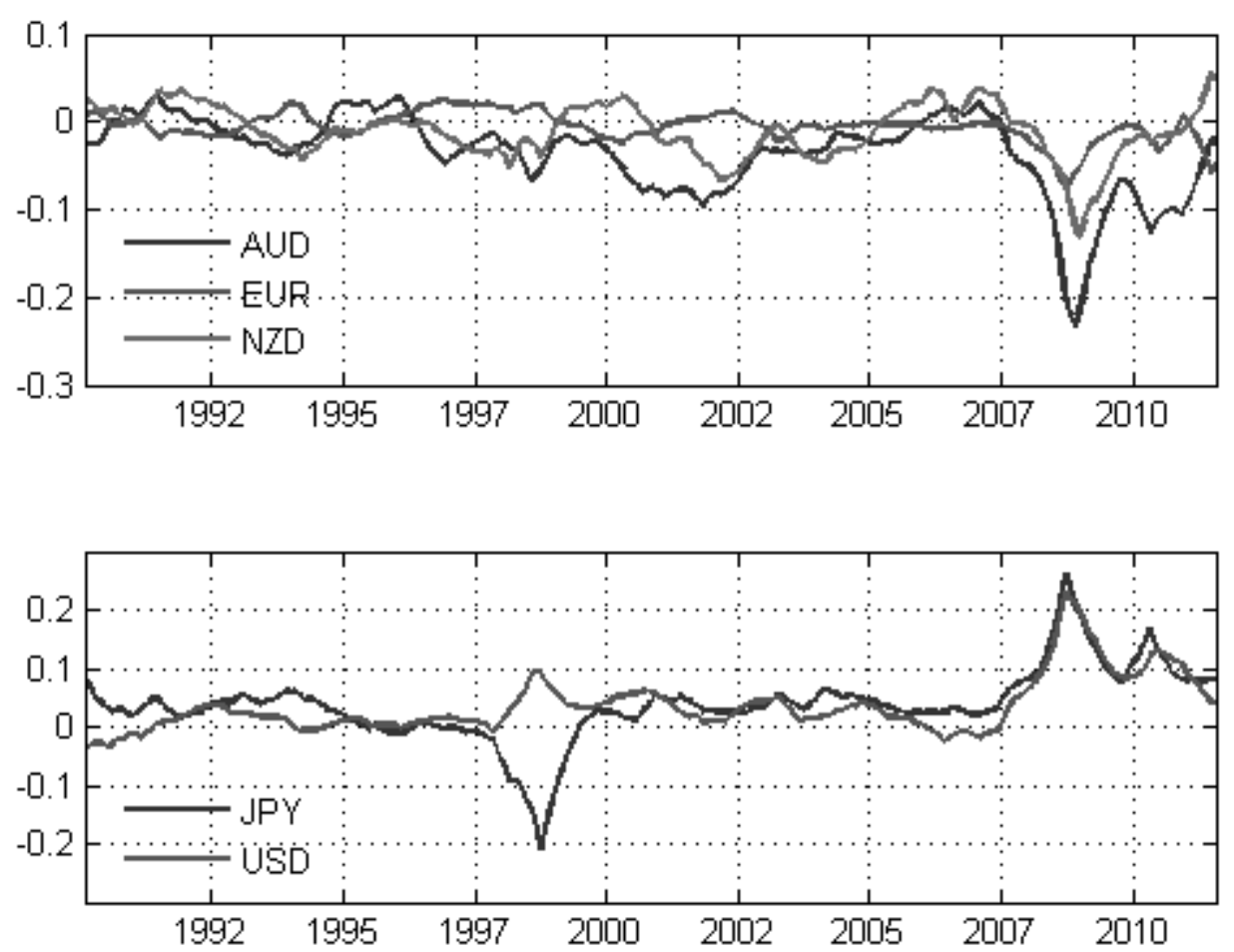

Figure 1: Estimates of the parameter paths of the coefficients from financial risk factor augmented UIP regression (15) for Swiss franc returns against the Australian dollar, the euro and the New Zealand dollar in the upper panel and against the Japanese Yen and the US dollar in the lower panel, computed following Müller and Petalas (2010). 


\section{Swiss National Bank Working Papers published since 2004:}

2004-1 Samuel Reynard: Financial Market Participation and the Apparent Instability of Money Demand

2004-2 Urs W. Birchler and Diana Hancock: What Does the Yield on Subordinated Bank Debt Measure?

2005-1 Hasan Bakhshi, Hashmat Khan and Barbara Rudolf: The Phillips curve under state-dependent pricing

2005-2 Andreas M. Fischer: On the Inadequacy of Newswire Reports for Empirical Research on Foreign Exchange Interventions

2006-1 Andreas M. Fischer: Measuring Income Elasticity for Swiss Money Demand: What do the Cantons say about Financial Innovation?

2006-2 Charlotte Christiansen and Angelo Ranaldo: Realized Bond-Stock Correlation: Macroeconomic Announcement Effects

2006-3 Martin Brown and Christian Zehnder: Credit Reporting, Relationship Banking, and Loan Repayment

2006-4 Hansjörg Lehmann and Michael Manz: The Exposure of Swiss Banks to Macroeconomic Shocks - an Empirical Investigation

2006-5 Katrin Assenmacher-Wesche and Stefan Gerlach: Money Growth, Output Gaps and Inflation at Low and High Frequency: Spectral Estimates for Switzerland

2006-6 Marlene Amstad and Andreas M. Fischer: Time-Varying Pass-Through from Import Prices to Consumer Prices: Evidence from an Event Study with Real-Time Data

2006-7 Samuel Reynard: Money and the Great Disinflation

2006-8 Urs W. Birchler and Matteo Facchinetti: Can bank supervisors rely on market data? A critical assessment from a Swiss perspective

2006-9 Petra Gerlach-Kristen: A Two-Pillar Phillips Curve for Switzerland

2006-10 Kevin J. Fox and Mathias Zurlinden: On Understanding Sources of Growth and Output Gaps for Switzerland

2006-11 Angelo Ranaldo: Intraday Market Dynamics Around Public Information Arrivals

2007-1 Andreas M. Fischer, Gulzina Isakova and Ulan Termechikov: Do FX traders in Bishkek have similar perceptions to their London colleagues? Survey evidence of market practitioners' views 
2007-2 Ibrahim Chowdhury and Andreas Schabert: Federal Reserve Policy viewed through a Money Supply Lens

2007-3 Angelo Ranaldo: Segmentation and Time-of-Day Patterns in Foreign Exchange Markets

2007-4 Jürg M. Blum: Why ‘Basel II’ May Need a Leverage Ratio Restriction

2007-5 Samuel Reynard: Maintaining Low Inflation: Money, Interest Rates, and Policy Stance

2007-6 Rina Rosenblatt-Wisch: Loss Aversion in Aggregate Macroeconomic Time Series

2007-7 Martin Brown, Maria Rueda Maurer, Tamara Pak and Nurlanbek Tynaev: Banking Sector Reform and Interest Rates in Transition Economies: Bank-Level Evidence from Kyrgyzstan

2007-8 Hans-Jürg Büttler: An Orthogonal Polynomial Approach to Estimate the Term Structure of Interest Rates

2007-9 Raphael Auer: The Colonial Origins Of Comparative Development: Comment. A Solution to the Settler Mortality Debate

2007-10 Franziska Bignasca and Enzo Rossi: Applying the Hirose-Kamada filter to Swiss data: Output gap and exchange rate pass-through estimates

2007-11 Angelo Ranaldo and Enzo Rossi: The reaction of asset markets to Swiss National Bank communication

2007-12 Lukas Burkhard and Andreas M. Fischer: Communicating Policy Options at the Zero Bound

2007-13 Katrin Assenmacher-Wesche, Stefan Gerlach, and Toshitaka Sekine: Monetary Factors and Inflation in Japan

2007-14 Jean-Marc Natal and Nicolas Stoffels: Globalization, markups and the natural rate of interest

2007-15 Martin Brown, Tullio Jappelli and Marco Pagano: Information Sharing and Credit: Firm-Level Evidence from Transition Countries

2007-16 Andreas M. Fischer, Matthias Lutz and Manuel Wälti: Who Prices Locally? Survey Evidence of Swiss Exporters

2007-17 Angelo Ranaldo and Paul Söderlind: Safe Haven Currencies 
2008-1 Martin Brown and Christian Zehnder: The Emergence of Information Sharing in Credit Markets

2008-2 Yvan Lengwiler and Carlos Lenz: Intelligible Factors for the Yield Curve

2008-3 Katrin Assenmacher-Wesche and M. Hashem Pesaran: Forecasting the Swiss Economy Using VECX* Models: An Exercise in Forecast Combination Across Models and Observation Windows

2008-4 Maria Clara Rueda Maurer: Foreign bank entry, institutional development and credit access: firm-level evidence from 22 transition countries

2008-5 Marlene Amstad and Andreas M. Fischer: Are Weekly Inflation Forecasts Informative?

2008-6 Raphael Auer and Thomas Chaney: Cost Pass Through in a Competitive Model of Pricing-to-Market

2008-7 Martin Brown, Armin Falk and Ernst Fehr: Competition and Relational Contracts: The Role of Unemployment as a Disciplinary Device

2008-8 Raphael Auer: The Colonial and Geographic Origins of Comparative Development

2008-9 Andreas M. Fischer and Angelo Ranaldo: Does FOMC News Increase Global FX Trading?

2008-10 Charlotte Christiansen and Angelo Ranaldo: Extreme Coexceedances in New EU Member States' Stock Markets

2008-11 Barbara Rudolf and Mathias Zurlinden: Measuring capital stocks and capital services in Switzerland

2008-12 Philip Sauré: How to Use Industrial Policy to Sustain Trade Agreements

2008-13 Thomas Bolli and Mathias Zurlinden: Measuring growth of labour quality and the quality-adjusted unemployment rate in Switzerland

2008-14 Samuel Reynard: What Drives the Swiss Franc?

2008-15 Daniel Kaufmann: Price-Setting Behaviour in Switzerland - Evidence from CPI Micro Data

2008-16 Katrin Assenmacher-Wesche and Stefan Gerlach: Financial Structure and the Impact of Monetary Policy on Asset Prices

2008-17 Ernst Fehr, Martin Brown and Christian Zehnder: On Reputation: A Microfoundation of Contract Enforcement and Price Rigidity 
2008-18 Raphael Auer and Andreas M. Fischer: The Effect of Low-Wage Import Competition on U.S. Inflationary Pressure

2008-19 Christian Beer, Steven Ongena and Marcel Peter: Borrowing in Foreign Currency: Austrian Households as Carry Traders

2009-1 Thomas Bolli and Mathias Zurlinden: Measurement of labor quality growth caused by unobservable characteristics

2009-2 Martin Brown, Steven Ongena and Pinar Yeșin: Foreign Currency Borrowing by Small Firms

2009-3 Matteo Bonato, Massimiliano Caporin and Angelo Ranaldo: Forecasting realized (co)variances with a block structure Wishart autoregressive model

2009-4 Paul Söderlind: Inflation Risk Premia and Survey Evidence on Macroeconomic Uncertainty

2009-5 Christian Hott: Explaining House Price Fluctuations

2009-6 Sarah M. Lein and Eva Köberl: Capacity Utilisation, Constraints and Price Adjustments under the Microscope

2009-7 Philipp Haene and Andy Sturm: Optimal Central Counterparty Risk Management

2009-8 Christian Hott: Banks and Real Estate Prices

2009-9 Terhi Jokipii and Alistair Milne: Bank Capital Buffer and Risk Adjustment Decisions

2009-10 Philip Sauré: Bounded Love of Variety and Patterns of Trade

2009-11 Nicole Allenspach: Banking and Transparency: Is More Information Always Better?

2009-12 Philip Sauré and Hosny Zoabi: Effects of Trade on Female Labor Force Participation

2009-13 Barbara Rudolf and Mathias Zurlinden: Productivity and economic growth in Switzerland 1991-2005

2009-14 Sébastien Kraenzlin and Martin Schlegel: Bidding Behavior in the SNB's Repo Auctions

2009-15 Martin Schlegel and Sébastien Kraenzlin: Demand for Reserves and the Central Bank's Management of Interest Rates

2009-16 Carlos Lenz and Marcel Savioz: Monetary determinants of the Swiss franc 
2010-1 Charlotte Christiansen, Angelo Ranaldo and Paul Söderlind: The Time-Varying Systematic Risk of Carry Trade Strategies

2010-2 Daniel Kaufmann: The Timing of Price Changes and the Role of Heterogeneity

2010-3 Loriano Mancini, Angelo Ranaldo and Jan Wrampelmeyer: Liquidity in the Foreign Exchange Market: Measurement, Commonality, and Risk Premiums

2010-4 Samuel Reynard and Andreas Schabert: Modeling Monetary Policy

2010-5 Pierre Monnin and Terhi Jokipii: The Impact of Banking Sector Stability on the Real Economy

2010-6 Sébastien Kraenzlin and Thomas Nellen: Daytime is money

2010-7 Philip Sauré: Overreporting 0il Reserves

2010-8 Elizabeth Steiner: Estimating a stock-flow model for the Swiss housing market

2010-9 Martin Brown, Steven Ongena, Alexander Popov, and Pinar Yeșin: Who Needs Credit and Who Gets Credit in Eastern Europe?

2010-10 Jean-Pierre Danthine and André Kurmann: The Business Cycle Implications of Reciprocity in Labor Relations

2010-11 Thomas Nitschka: Momentum in stock market returns: Implications for risk premia on foreign currencies

2010-12 Petra Gerlach-Kristen and Barbara Rudolf: Macroeconomic and interest rate volatility under alternative monetary operating procedures

2010-13 Raphael Auer: Consumer Heterogeneity and the Impact of Trade Liberalization: How Representative is the Representative Agent Framework?

2010-14 Tommaso Mancini Griffoli and Angelo Ranaldo: Limits to arbitrage during the crisis: funding liquidity constraints and covered interest parity

2010-15 Jean-Marc Natal: Monetary Policy Response to Oil Price Shocks

2010-16 Kathrin Degen and Andreas M. Fischer: Immigration and Swiss House Prices

2010-17 Andreas M. Fischer: Immigration and large banknotes

2010-18 Raphael Auer: Are Imports from Rich Nations Deskilling Emerging Economies? Human Capital and the Dynamic Effects of Trade 
2010-19 Jean-Pierre Danthine and John B. Donaldson: Executive Compensation: A General Equilibrium Perspective

2011-1 Thorsten Beck and Martin Brown: Which Households Use Banks? Evidence from the Transition Economies

2011-2 Martin Brown, Karolin Kirschenmann and Steven Ongena: Foreign Currency Loans Demand or Supply Driven?

2011-3 Victoria Galsband and Thomas Nitschka: Foreign currency returns and systematic risks

2011-4 Francis Breedon and Angelo Ranaldo: Intraday patterns in FX returns and order flow

2011-5 Basil Guggenheim, Sébastien Kraenzlin and Silvio Schumacher: Exploring an uncharted market: Evidence on the unsecured Swiss franc money market

2011-6 Pamela Hall: Is there any evidence of a Greenspan put?

2011-7 Daniel Kaufmann and Sarah Lein: Sectoral Inflation Dynamics, Idiosyncratic Shocks and Monetary Policy

2011-8 Iva Cecchin: Mortgage Rate Pass-Through in Switzerland

2011-9 Raphael A. Auer, Kathrin Degen and Andreas M. Fischer: Low-Wage Import Competition, Inflationary Pressure, and Industry Dynamics in Europe

2011-10 Raphael A. Auer and Philip Sauré: Spatial Competition in Quality, Demand-Induced Innovation, and Schumpeterian Growth

2011-11 Massimiliano Caporin, Angelo Ranaldo and Paolo Santucci de Magistris: On the Predictability of Stock Prices: a Case for High and Low Prices

2011-12 Jürg Mägerle and Thomas Nellen: Interoperability between central counterparties

2011-13 Sylvia Kaufmann: K-state switching models with endogenous transition distributions

2011-14 Sébastien Kraenzlin and Benedikt von Scarpatetti: Bargaining Power in the Repo Market

2012-01 Raphael A. Auer: Exchange Rate Pass-Through, Domestic Competition, and Inflation: Evidence from the 2005/08 Revaluation of the Renminbi

2012-02 Signe Krogstrup, Samuel Reynard and Barbara Sutter: Liquidity Effects of Quantitative Easing on Long-Term Interest Rates 
2012-03 Matteo Bonato, Massimiliano Caporin and Angelo Ranaldo: Risk spillovers in international equity portfolios

2012-04 Thomas Nitschka: Banking sectors' international interconnectedness: Implications for consumption risk sharing in Europe

2012-05 Martin Brown, Steven Ongena and Pinar Yeşin: Information Asymmetry and Foreign Currency Borrowing by Small Firms

2012-06 Philip Sauré and Hosny Zoabi: Retirement Age across Countries: The Role of Occupations

2012-07 Christian Hott and Terhi Jokipii: Housing Bubbles and Interest Rates

2012-08 Romain Baeriswyl and Camille Cornand: Reducing overreaction to central bank's disclosures: theory and experiment

2012-09 Bo E. Honoré, Daniel Kaufmann and Sarah Lein: Asymmetries in Price-Setting Behavior: New Microeconometric Evidence from Switzerland

2012-10 Thomas Nitschka: Global and country-specific business cycle risk in time-varying excess returns on asset markets

2012-11 Raphael A. Auer, Thomas Chaney and Philip Sauré: Quality Pricing-to-Market

2012-12 Sébastien Kraenzlin and Thomas Nellen: Access policy and money market segmentation

2012-13 Andreas Kropf and Philip Sauré: Fixed Costs per Shipment

2012-14 Raphael A. Auer and Raphael S. Schoenle: Market Structure and Exchange Rate Pass-Through

2012-15 Raphael A. Auer: What Drives Target2 Balances? Evidence From a Panel Analysis

2012-16 Katja Drechsel and Rolf Scheufele: Bottom-up or Direct? Forecasting German GDP in a Data-rich Environment

2013-01 Andreas Kettemann and Signe Krogstrup: Portfolio balance effects of the SNB's bond purchase program

2013-02 Nicole Aregger, Martin Brown and Enzo Rossi: Transaction Taxes, Capital Gains Taxes and House Prices

2013-03 Simone Meier: Financial Globalization and Monetary Transmission 
2013-04 Christian Grisse and Thomas Nitschka: On financial risk and the safe haven characteristics of Swiss franc exchange rates 
Swiss National Bank Working Papers are also available at www.snb.ch, section Publications/Research Subscriptions or individual issues can be ordered at Swiss National Bank, Fraumünsterstrasse 8, CH-8022 Zurich, fax +41 4463181 14, E-mail library@snb.ch 